\title{
Women's Experience of Vulnerability in Flood in the context of Northern Region of Bangladesh
}

\author{
Marjina Masud1, Md. Mahabub Chowdhury ${ }^{2 *}$, Farhana Kamal ${ }^{3}$ \\ ${ }^{1}$ Technical Specialist - GEMS (JANO), Plan International Bangladesh -Rangpur Divisional \\ Office, BANGLADESH \\ ${ }^{2 *}$ Lecturer, Department of Development Studies, Hajee Mohammad Danesh Science and Technology \\ University, BANGLADESH \\ ${ }^{3}$ Lecturer, Department of Sociology, Hajee Mohammad Danesh Science and Technology \\ University, BANGLADESH \\ *(mahabubds.hstu@gmail.com)
}

This journal is licensed under a Creative Commons Attribution-Noncommercial 4.0 International License (CC-BY-NC). Articles can be read and shared for noncommercial purposes under the following conditions:

- BY: Attribution must be given to the original source (Attribution)

- NC: Works may not be used for commercial purposes (Noncommercial)

This license lets others remix, tweak, and build upon your work non-commercially, and although their new works must also acknowledge you and be non-commercial, they don't have to license their derivative works on the same terms. License Deed Link: http://creativecommons.org/licenses/by-nc/4.0/ Legal Code Link: http://creativecommons.org/licenses/by-nc/4.0/legalcode $A B C$ Research Alert uses the CC BY-NC to protect the author's work from misuse.

\begin{abstract}
Flood is one of the most common and devastating disasters in the northern region of Bangladesh. The objective of this research is to investigate how and to what extent flood has been affecting people's livelihood and how men and women are taking steps to mitigate the impact and cope up with the situation. The research work was conducted based on a qualitative point of view and the lens of feminist research methodology. This study has revealed that flood-induced vulnerability affects men and women differently. Women experience the severity of the flood and household food insecurity much more than men as women are responsible for maintaining the household, taking care of everyone, and playing the role of buffer and absorber the impact. To mitigate the impact and cope up with the devastating effects of floods, men and women employ different strategies. While men go to nearer or far towns or cities for alternative livelihoods, women remain within the household and try to mitigate the impact. This study is conducted through qualitative research techniques such as semi-structured interview, focus group discussion, case study, and conversational exchange method and aims at contributing to a broader understanding of women's experience of flood-induced vulnerability in the context of the northern region of Bangladesh.
\end{abstract}

\section{Keywords}

Flood, Vulnerability, Women, Coping Strategy.

\section{INTRODUCTION}

Bangladesh is one of the most disaster-affected countries in the world and extremely vulnerable to climate change-induced natural disasters. Different natural disasters in Bangladesh have been increasing in recent years which has caused destruction and devastation in people's lives, livelihood, property, and security. Among all the disasters, flood is one of the most common and considered a threat to human lives and livelihood. Parvin et al. (2016) claimed that among the varied risks and disasters, the flood is the commonest and frequent. About $70 \%$ of the population of Bangladesh is at risk of floods ((Parvin et al., 2016). According to Rahman (2014), the flood destroys standing crops, dwellings, 
infrastructure, machinery, and buildings, and most importantly tragic loss of lives and reduce the assets of households, communities, and societies. Kabir and Hossen (2019) state that most of Bangladesh are low lying where $80 \%$ of the landmass is flood plain making it having a place for the occurrence of flooding.

The northern part of Bangladesh has been a victim of floods every year. Several important rivers enter Bangladesh through the northern border. Among them, the Kurigram district has been a major route for several rivers entering Bangladesh. Major rivers of Kurigram include Brahmaputra, Tista, Dharla (Bangladesh National Portal, 2020). In recent years, the people of Kurigram have seen extreme forms of flood and its devastating effects on people's lives. The water level in Brahmaputra, Teesta, Dharla, and Dudhkumar raised causing floods and damage to the people's lives (Dhaka Tribune, 2018) Another report of the same national daily newspaper says 17,135 hectares of croplands in Kurigram were inundated by flood in 2020 (Islam, 2020).

The adverse effects of the flood are different for different groups of people such as men, women, children, elderly and disabled individuals. The impact of natural disasters on people's life and livelihood depends on certain conditions such as geographical location or people's income level (Carey, cited in Rahman 2014). Vulnerability to the effects of disasters on the population is determined by the social and economic structure of a society (Usman et al., 2013). Because of the position of women, the patriarchal feature of society, women's needs, level, and perception of risks, vulnerabilities, and capacities are different in comparison to those of men (Azad et al., 2013).

The impact of floods on the poor, especially those living in flood-prone rural areas is greater. Women have a unique relationship with the river. Because of the existing gender roles and status of women in society, women experience vulnerability to flood differently than men. According to Ferdous and Mallick (2019), because of the prevailing gender roles, social structures and cultural norms women of South Asia have unique relations with rivers. The objective of this research is to critically analyze women's vulnerabilities to flood and coping strategies employed to fight against the flood-induced sufferings. In the light of the focus on women's subjective experience, a narrative approach has been adopted to explore their vulnerability to flood and the coping strategies they take through their narratives and voices. To bring an analysis, the following major questions were considered and investigated in this research.

- How do women experience the adverse effects of vulnerability to flood?

- How people's lives and livelihoods are being affected by the vulnerability to flood?

- What are the coping strategies adopted by women and men to fight against flood-driven vulnerabilities and difficulties?

\section{SIGNIFICANCE OF THE STUDY AND LITERATURE REVIEW}

Rivers are the lifeline of Bangladesh. Bangladesh is a riverine country with around 700 rivers (Banglapedia - the National Encyclopedia of Bangladesh, 2021c). The people of Bangladesh have a deep root and connection with rivers. Food, water, moods of communication, agriculture, transportation, water resources, and other socio-cultural activities are some of the factors for people's dependence and connection with the river in Bangladesh (Mirchandani, 2016). People of Bangladesh face different disasters every year. River and disasters are often well connected. According to Hossain et al. (2013), Bangladesh is vulnerable most to several natural disasters and people's lives in some parts of the country are being upset every year by natural calamities. Hossain et al. (2013) cite that the major disasters concerned here are the occurrences of flood, cyclone and storm surge, flash flood, drought, tornado, riverbank erosion, and landslide. Notable research work has been conducted so far concerning riverrelated disasters and calamities. Studies have also been done concerning the adverse effects such riverrelated disasters. Rahman (2013) states that even in a normal year, almost half of the country undergoes flood and inundation bringing flood-related risks. More or less every year, the flood has visited Bangladesh and often has been within tolerable limits and occasionally they become devastating. BBS 
(2013) states that every year in Bangladesh about 26,000 sq. km. (18\% of the country) area is flooded. In an average year, 844000 million cubic meters of water flow into the country during the humid period (May to October) through the key rivers the Ganges, the Brahmaputra, and the Meghna which is 95\% of the total annual inflow (Banglapedia - the National Encyclopedia of Bangladesh, 2020b). As the majority of the people in Bangladesh live in rural areas, their lives and livelihoods are directly and indirectly dependent on land and water. Frequent and devastating flooding jeopardizes the lives and livelihood of these people (Parvin et al., 2016).

Almost all regions of Bangladesh are affected by natural disasters. But among them, the northern region is one of the most affected because of its geographical location and demographic condition. Geographically people of the northern region are living in a vulnerable context because of the availability of many rivers and the adverse effect of political ecology. Every year, people of this region experience floods, drought, riverbank erosion, and cyclones causing huge loss including breaking the food security through crop damage. According to a report published in a daily newspaper, in 2020, rampaged flooding inundated northern Bangladesh and caused severe damage and suffering in the middle of the COVID-19 crisis (Al Amin, 2020). Another report published in Dhaka Tribune says water kept rising in 16 local rivers, and 22 unions of nine Upazilas in Kurigram have been marooned affecting one lakh people in the reporting period (Dhaka Tribune, 2020). Vulnerability to flood is determined and influenced by several different factors as the vulnerability to any disasters. According to Goodrich et al. (2019), several interlinked contextual factors such as gender, political, socio-economic, and geographical and biophysical issues influence the vulnerability to climate and environmental changes. Paul (2014) claims that factors like tropical monsoon climate and floodplain topography make the northern region of Bangladesh vulnerable owing to different forms of natural calamities such as riverbank erosion, flood, drought, and cold waves.

The same interconnection applies in the context of vulnerability to flood. The northern region has been identified as the most poverty-stricken part of Bangladesh. According to the 2016-17 Household Income and Expenditure Survey (HIES) quoted in the report of the World Bank, 24.3 percent of the population live in poverty whereas 2.9 percent of the population live in extreme poverty (World Bank, 2017). Northern Bangladesh faces the extreme adverse effects of such poverty. According to Elahi and Ara (2008), factors like heavy dependence on agriculture, economic diversification, survival of landless and poorest people on agriculture by selling labor, change of climate, limited working opportunities strengthening poverty and hunger situation of people which also termed as seasonal poverty in the north of Bangladesh. Several studies have been conducted concerning poverty in Kurigram. Factors like cultural barriers, socio-economic insolvency, natural disasters, lack of employment, and industry deployed people of Kurigram to poor situations in northern Bangladesh (Barman and Islam, 2020).

The effect of disaster is different for men and women because of their gender identity. Equally, the adverse effects of the flood are also different for women and men. Different studies have concentrated on the issue of the gender-differentiated impact of flood or other river-related disasters. Ferdous and Mallick (2019) analyzed that because of the socio-cultural norms and values, education, gender roles, and unequal access to property and resources women have different kinds of relationship with the river than their male counterparts. Women are socially and economically less privileged than men in Bangladesh (Kashem and Faroque, cited in Yufonyuy 2015). There are inequalities between men and women in almost all spheres of society such as education, health, employment, and income opportunities, (Haque and Itohara, citied in Sharmin 2014). Women's heavy domestic workloads, their restricted mobility, their limited access and power over household resources, their poor knowledge and skills, their restricted role in household decision making, and low level of individual assets makes them vulnerable (Sebstad and Cohen, cited in Parveen and Leonhäuser 2004).

The disadvantaged condition makes women more vulnerable to flood. To fight against vulnerability, women and men often employ or use different kinds of techniques and alternatives to cope up in extreme conditions. Both affected men and women seek alternative livelihoods to cope up with the hazardous situation (Sultana et al., 2018). 
All the above-discussed analysis and research work show how northern Bangladesh has been affected by flood especially how women are disproportionately affected by the adverse effects of vulnerability to flood. Understanding women's perspectives regarding their vulnerability to flood is of immense significance to identify the underlying factors of how women experience the vulnerability to flood from an intersectional perspective. There are a lot of studies concerning vulnerability to flood in Bangladesh and the northern part of the country as well. This study extensively focuses on women's experience of flood and flood-induced vulnerability along with their efforts to cope up with the situation and concentrates on bringing the narratives of women's subjective experience to draw a consolidated picture of women and flood in the context of northern Bangladesh. The study will help us to better understand women's gender-differentiated experience of vulnerability to flood from a narrative and qualitative point of view and contribute to the identification of the opportunities of future research on the topic.

\section{RESEARCH METHODOLOGY}

The research methodology of a particular research topic depends on the nature of the problem, rationale, objectives, subject area, assumption, and logic behind it. This study concentrates on reviewing and investigating women's experience of vulnerability to flood with the narratives of subjective experience, women's sufferings, and coping techniques. The mentioned research topic is well-connected with women's development agenda. This has made it similar to feminist research methodology. As a result, qualitative research methodology is relevant in this regard. Therefore, a qualitative research approach is used in this research to provide an in-depth understanding of the perspectives, experiences, and insights of research participants.

\subsection{Primary Data}

Semi-structured interview, focus group discussion, conversational exchange, and case study method were used for collecting data from primary sources. The primary data were collected from June 2020 to October 2020 following standard guidelines and research ethical consideration along with the consent of respondents.

\subsection{Secondary Data}

Along with the primary data, secondary data played a significant role in this research. National and international reports on floods in Bangladesh, research reports, news reports, journal articles on the relevant topic are the secondary source of data in this research.

\subsection{Population}

Flood-affected women and men are the key populations as this research intends to investigate the women's experience of vulnerability to flood compare to their male counterparts.

\subsection{Sampling Procedure}

The purposive sampling method is used in this research which has the compatibility to study a small portion of the target population. The number of the population affected by floods in northern Bangladesh is huge. It is not possible to reach every single individual for the research purpose. Therefore, the purposive sampling method is used to get relevant and profound insights into the desired data for this study. Communication, time, distance, transportation, consents of the respondents, and COVID19 crisis have been considered in the selection of the respondents of this research.

\subsection{Study Setting}

This research is conducted in Chilmari Upazila of Kurigram district situated in the northern part of Bangladesh. Chilmari is intersected by different water bodies and rivers. Major water bodies and rivers of Chilmari includes Brahmaputra, Chaslar Beel, Udnar Beel, Magurar Beel, Shouldhukrir Beel, Pedi Theorar Beel, and Horinnar Bandha Beel making it one of the most flood-prone areas of Kurigram (Banglapedia - the National Encyclopedia of Bangladesh, 2020a). People of Chilmari face extreme 
floods and flood-induced vulnerability every year. According to a report of a national daily newspaper, the Brahmaputra River was flowing $73 \mathrm{~cm}$ above the danger level at Chilmari point in 2020 (The Daily Star, 2020). Chilmari Upazila of Kurigram district is selected using the purposive sampling method because of its owing to the relevance of factors available for this research.

\subsection{Data Collection}

In this study, interviews of 100 respondents comprising 50 women and 50 men through a semistructured interview method were taken. In some cases, interviews were recorded along with the consent of the respondents following a standard ethical guideline. This semi-structured interview questionnaire has been developed focusing on various issues including the demographic condition of the respondents, how they experience disaster particularly flood and to what extent they suffer from flood induced vulnerability at different levels of their lives, and what are those strategies they follow to cope up with the adverse situation. Men respondents were included to understand women's unique experience of vulnerability to flood from a comparative point of view. Two Focus Group Discussion were conducted in this study. One with both women and men and another with women only to explore the in-depth information for this research. In addition to this, the conversation exchange method and case study method are also used in this research to gather in-depth and descriptive information for this research purpose.

\subsection{Method of Analysis}

Qualitative data analysis techniques have been used in this research while analyzing the collected data. Techniques such as reformation of narratives, opinions, and experiences of the respondents, classification, categorization, summarization of data, and transcription were done as per the standard procedure to meet the research ethics, quality, and research objectives. Microsoft Office application has been used for data analysis, computation, and report composition. In order to develop analysis and arguments, both primary and secondary data, and relevant scholarship were merged based on careful and systematic consideration and logical explanation with the narrative and qualitative findings. The authors' observations were also incorporated in the development of arguments and analysis.

\subsection{Problem Encountered in the Field}

Time for an in-depth discussion was a major concern during the data collection. Most of the respondents are living in a condition where they have to work every single day for earning a livelihood. In this context, getting enough time for the discussion has been a challenge. A major portion of the data collection was done during the flood situation. As a result, the mentality of the respondents for relief goods from the field enumerator caused problems while collecting data. This has slowed down the speed of data collection to find quality respondents. Another important factor is the COVID-19 pandemic. Collecting data in the middle of the COVID-19 pandemic was a challenge. Thus, data was collected, enumerated, and analyzed according to the standard health measures and procedures.

\subsection{Ethical Consideration}

This study has been conducted following a standard and strict ethical guideline of research. Respondents were informed and explained the aim and scope of the research along with their implication of the involvement in the research before conducting data collection. Consents were also taken prior to any recording of the interviews. Added to this, the confidentiality and privacy of the respondents and their interviews have been maintained strictly. Standard health measures in the context of the COVID-19 crisis were maintained including social distancing in all stages of this research.

\section{FINDINGS AND DISCUSSION}

In this study, a total of 100 respondents were interviewed comprising of 50 women and 50 men. According to the data collected from the research setting, in the context of the educational background of women, $18 \%$ of women can sign only while $44 \%$ have attended primary school, $26 \%$ attended high school, and $12 \%$ have 
passed the SSC examination. In terms of the occupation of women, $12 \%$ of them were housewives, $44 \%$ were housewives and seasonal day laborers at the same time, $34 \%$ were a farmer and seasonal day laborer, $10 \%$ own small venture. Data also suggests that $6 \%$ of women respondents were unmarried, $68 \%$ were married, $12 \%$ were widowed and $14 \%$ were abandoned by their husbands and husbands' family.

\begin{tabular}{|c|c|c|c|c|}
\hline \multirow[t]{2}{*}{ Respondents } & \multicolumn{2}{|c|}{ Men } & \multicolumn{2}{|c|}{$50 \%$} \\
\hline & \multicolumn{2}{|c|}{ Women } & \multicolumn{2}{|c|}{$50 \%$} \\
\hline \multicolumn{5}{|c|}{ Women } \\
\hline \multirow[t]{2}{*}{ Education } & Can Sign Only & Primary & High School & SSC \\
\hline & $18 \%$ & $44 \%$ & $26 \%$ & $12 \%$ \\
\hline \multirow[t]{2}{*}{ Age } & $18-30$ & $31-40$ & $41-50$ & $51-60$ \\
\hline & $28 \%$ & $30 \%$ & $30 \%$ & $12 \%$ \\
\hline \multirow[t]{2}{*}{ Occupation } & Housewife & $\begin{array}{c}\text { Housewife and } \\
\text { Seasonal Day } \\
\text { Laborer }\end{array}$ & $\begin{array}{c}\text { Farmer and Seasonal } \\
\text { Day Labor }\end{array}$ & $\begin{array}{c}\text { Small Venture/Small } \\
\text { Business }\end{array}$ \\
\hline & $12 \%$ & $44 \%$ & $34 \%$ & $10 \%$ \\
\hline \multirow[t]{2}{*}{ Marital Status } & Unmarried & Married & Widow & Abandoned \\
\hline & $6 \%$ & $68 \%$ & $12 \%$ & $14 \%$ \\
\hline \multirow[t]{2}{*}{$\begin{array}{l}\text { Head of the } \\
\text { Households }\end{array}$} & \multicolumn{2}{|c|}{ Men } & \multicolumn{2}{|c|}{ Women } \\
\hline & \multicolumn{2}{|c|}{$58 \%$} & \multicolumn{2}{|c|}{$42 \%$} \\
\hline \multicolumn{5}{|c|}{ Men } \\
\hline \multirow[t]{2}{*}{ Education } & Can Sign Only & Primary & High School & SSC \\
\hline & $22 \%$ & $34 \%$ & $32 \%$ & $12 \%$ \\
\hline \multirow[t]{2}{*}{ Age } & $18-30$ & $31-40$ & $41-50$ & $51-60$ \\
\hline & $34 \%$ & $36 \%$ & $22 \%$ & $8 \%$ \\
\hline \multirow[t]{2}{*}{ Occupation } & $\begin{array}{l}\text { Farmer (Cultivate } \\
\text { on Own Land) }\end{array}$ & $\begin{array}{c}\text { Agricultural } \\
\text { Laborer \& Day } \\
\text { Laborer } \\
\end{array}$ & $\begin{array}{l}\text { Farmer (Cultivate on } \\
\text { Own Land) \& Sea- } \\
\text { sonal Day Laborer }\end{array}$ & Small Venture/Business \\
\hline & $22 \%$ & $36 \%$ & $34 \%$ & $8 \%$ \\
\hline \multirow[t]{2}{*}{ Marital Status } & Unmarried & Married & \multicolumn{2}{|c|}{ Widow } \\
\hline & $12 \%$ & $80 \%$ & \multicolumn{2}{|c|}{$8 \%$} \\
\hline \multirow[t]{2}{*}{$\begin{array}{l}\text { Head of the } \\
\text { Households }\end{array}$} & \multicolumn{2}{|c|}{ Men } & \multicolumn{2}{|c|}{ Women } \\
\hline & \multicolumn{2}{|c|}{$94 \%$} & \multicolumn{2}{|c|}{$6 \%$} \\
\hline
\end{tabular}

*Source: Semi-structured Interview, 2020

Table 1. Profile of the Respondents

In the case of their head of the household, $58 \%$ were headed by men, and the rest $42 \%$ were headed by women. In the case of male respondents, it is found that $22 \%$ can sign only, $34 \%$ have attended primary school, $32 \%$ have attended high school, and $12 \%$ have passed the SSC examination. Data shows that 22\% of men are farmers who cultivate their land, 26\% work as an agricultural laborer and day laborer, $34 \%$ are small-farmer who cultivates on own land and work as a seasonal day laborer at the same time, and $8 \%$ men own small business or venture. In terms of marital status, $12 \%$ were found unmarried, $80 \%$ were married and $8 \%$ were found as a widow. In addition to this, among the household of male respondents, $94 \%$ were headed by male members while $6 \%$ were found to be headed by a female. In the case of this $6 \%$ femaleheaded household, the respondents are young and their mothers or elderly women members play the role of head of those particular households.

As day laborers, women work in the different projects of construction of dam and road, and maintenance of infrastructural components as well as agricultural laborer of nearer sources. It is found that men have the mobility to move to nearby and far villages and towns for agricultural laborer or other work while women do not have similar access. The study shows that women are less likely to be paid for doing the same work as men.

\begin{tabular}{|c|c|}
\hline Women & Tk. $120-150$ \\
\hline Men & Tk. 200-250 \\
\hline
\end{tabular}

Table 2. Daily Income of Men and Women as Day Laborer and Agricultural Laborer *Source: Semi-structured Interview, 2020 
According to the responses and collected data, women approximately earn only Tk. 3,000/- to Tk. 5,500/- per month while men earn approximately Tk. 6,000/- to Tk. 7,500/- per month. This low income leads women to more poverty and experience severity of disaster particularly in the household level more than of the male counterparts. Moreover, as women cannot go out from their village, they have limited scope to work in all 30 days of a month while men can do so as they can move from their villages to another, towns and even far away from their ones. Holding small businesses also gives men more security than women. Women are likely to have small capital than men in case of owning and running a small business.

All respondents including men and women reported that they cannot work for all twelve months without any interruption. They remain work less because of the flood, as flood disrupts all of the agricultural lands and spoils other work sources, especially during the monsoon. To earn their subsistence, men go to the nearer and far cities and towns while women cannot do so as they look after the family. This picture is also the same for the female-headed households.

The findings report that most men and women are of the study setting living such as economic vulnerability context where they own either very little or no land. Though a few of them own only a very small proportion of land, they face the risk of losing them as a consequence of flood and riverbank erosion. According to the findings, $50 \%$ decision regarding the basic familial issue is taken only by the men within the family and in $20 \%$ cases, women have access to decide basic familial issues along with man jointly. These findings also suggest that only $15 \%$ of women have sole access to the decisionmaking regarding the crucial familial issues including selling or buying assets, marriage, and even disaster-related issues while men take such decisions solely in $70 \%$ of cases. In $15 \%$ of families, men and women take these decisions jointly regarding the crucial familial issue.

The flood comes every year, sometimes twice a year with extreme impact on the people living in the region. The basic demographic condition and social and economic standing of the people living in the region have made people more vulnerable. The household infrastructures were found in very poor condition and their poverty is also making them vulnerable during and post-flood periods. The study finds that $70 \%$ of households are made of 'Jhupri', $15 \%$ are Bamboo made, and the rest $15 \%$ are of Tin Shed house. They are unable to build more strong houses and they have to stay in these houses building on dams, roadside areas, governmental land (Khas), and others people's land. The devastating impact of riverbank erosion as a result of severe floods has made their housing and accommodation more insecure.

Almost all respondents report that they experience the extreme impact of floods every year. When a flood occurs, women experience more vulnerability than men. Women of the region live in a traditional social context where women are the primary caregiver of the family. Childbearing and child-rearing are one of their primary responsibilities. They also look after the family, look after the elder member and work outside the home to contribute to the family's livelihood. In the case of female-headed households, women are also playing the same role and maintain the whole family and work outside the home to earn livelihood to look after the family as the head. Women of the female-headed household suffer from severe poverty during the flood time. They earn a very small amount of money and unable to save it for the future. As a consequence, they face food scarcity during the flood in the household, reported by the respondents. As these women are of poor families they have to work outside their home to support their families financially. It seems to empower them enabling them to go beyond the four walls of the household. But in reality, they only become able to do so because of their poor economic condition and as a way to mitigate the extreme impact of the flood through earning livelihood and subsistence and contributing to the family livelihood. This is creating extra pressure on them instead of empowering them. Women's lower access to decision-making in both basic and crucial familial issues also contribute to the severe vulnerability of women to flood. They can barely say anything regarding the disasterrelated issues including when to go to the safe area, whether they can go out to earn or not, choosing their occupation, buying and selling family assets and property, and also maintaining the social network. In families, women take food last of all. They feed all of their family members first including husband, 
children, and elders, and take last what remains. It has been noticed that they barely can eat enough in times of flood-induced vulnerabilities and sufferings. When a flood occurs, women become responsible to feed all of the family members no matter whether they have got food available in the house or not. Sometimes, cattle are being reared for income diversification to mitigate the impact of the flood. Managing or collecting food for cattle is tough for women and it becomes an extra burden to them. Limited food intake for girls and women in the family for the above-mentioned factors leading from flood-induced food insecurity at the household level has been contributing to malnutrition of girls and women. Though men and women both are affected by malnutrition, women are the worst victim of this crisis.

Another widely discussed effect of the flood is its impact on the schooling of boys and girls. In most of the cases, which is found in this study, educational opportunities are disrupted during and after flood situations. During the flood, respondents have reported that it becomes impossible to continue school. This hindrance the educational opportunity and further leads to early marriage for girls in most of the cases and boys in a few cases. At the same time, boys are required to work to contribute to family livelihood. Violence against women is also propagated within the household in times of flood-induced crisis when the husband gets frustrated because of vulnerable socio-economic conditions.

It is found that people employ diversified strategies to cope up with flood situations and mitigate the impact of the flood. As the roles and responsibilities are different for men and women and there is a difference in how they experience the severity of flood and flood induced crisis including food insecurity, coping strategies are different for men and women. Strategies employed by women include saving money for flood time and saving food particularly dry food that helps in times of food shortage, changing the food menu depending on food price, rearing cattle and cultivating vegetables in domestic land, and reducing meals from three-time to two times in a day. They also involve themselves in incomegenerating activities. In the case of men, strategies include borrowing money from others, going to nearer and far villages and towns for income diversification, maintaining the social network, and managing and collecting relief aids.

Findings suggest that $35 \%$ of people depend on relief, sometimes eat only one meal in a day, borrow money, husband or son goes town or other places for employment. In cases of female-headed households, people depend on relief, sometimes eat only one meal in a day, borrow money, try to go out for work to help the family and earn a livelihood. Education and seeking medical treatment are crucial for these households in times of flood and post-flood situations. It is also found that, in the case of solvent families, women do not work outside their households to earn a livelihood, they have limited access to decision making, and experience greater control of wage earner male members of the family. Femaleheaded households are also found to have more pre-disaster preparation than male-headed households.

\section{CONCLUSION}

The present study is an effort to explore the subjective experience of women's vulnerability to flood in northern Bangladesh. Because of geographical conditions, the northern region of Bangladesh is vulnerable to flood and flood-induced devastations every year. People experience the devastating effects of the flood on their lives and livelihood leading towards irreplaceable damage in all manner. It is found that the impact of and vulnerability to flood vary between men and women. Women are in more vulnerable condition than men as they are the buffer and absorber of their families in any disaster situation. Flood affects the food production system causing damage to agricultural products and also limits the opportunity of work. Men and women both lose their work opportunities. For women, the wage and sources of income are both limited and lower than men. Women are also less paid for the same work than men. Flood also leads to riverbank erosion causing loss of agricultural land and accommodation. Losing agricultural land also hinder employment opportunities as an agricultural laborer. Women's traditional role as a caregiver and buffer and absorber of family crisis has made them experience the extreme vulnerability to flood. In the case of coping strategies, men and women employ different types of tactics and interventions to mitigate the adverse effects of the flood. Issues like 
poverty, traditional gender roles, and geographical location are some of the major intersectional factors influencing the degree of women's vulnerability to flood as well as their coping strategies.

\section{Acknowledgements}

We appreciate and acknowledge the efforts and hard work of all field enumerators. We are also grateful to all of the respondents for their support and time. We would like to thank the local guide for his support, arrangement, and assistance during the whole process of data collection. This research work has been conducted based on authors' personal funding.

\section{REFERENCE}

Al Amin, M. (2020). Rampaging floods inundate Northern Bangladesh. [online] Dhaka Tribune. Available at: https://www.dhakatribune.com/bangladesh/nation/2020/06/28/flood-situation-may-worsen-over-next-4-5days [Accessed 20 Dec. 2020].

Azad, A.K., Hossain, K.M. and Nasreen, M. (2013). Flood-induced vulnerabilities and problems encountered by women in northern Bangladesh. International Journal of Disaster Risk Science, [online] 4(4), pp.190-199. Available at: https://link.springer.com/content/pdf/10.1007/s13753-013-0020-z.pdf [Accessed 30 Jun. 2020].

Bangladesh National Portal (2020). Kurigram District. [online] Bangladesh National Portal. Available at: http://www.kurigram.gov.bd/site/page/6ecd5c03-18fd-11e7-9461286ed488c766/\%E0\%A6\%AD\%E0\%A7\%8C\%E0\%A6\%97\%E0\%A7\%8B\%E0\%A6\%B2\%E0\%A6\%BF\% Е0\%А6\%95\%20\%Е0\%A6\%AA\%Е0\%А6\%B0\%Е0\%А6\%ВF\%Е0\%A6\%9A\%Е0\%A6\%BF\%Е0\%A6\%A4 $\%$ E0\% A6\%BF [Accessed 22 May 2020].

Banglapedia - the National Encyclopedia of Bangladesh (2020a). Chilmari Upazila. [online] Banglapedia. Available at: https://en.banglapedia.org/index.php/Chilmari_Upazila [Accessed 12 May 2020].

Banglapedia - the National Encyclopedia of Bangladesh (2020b). Flood -. [online] Banglapedia. Available at: https://en.banglapedia.org/index.php/Flood\#: :text=During\%20severe\%20floods\%2C\%20the\%20affected [Accessed 22 Jun. 2020].

Banglapedia - the National Encyclopedia of Bangladesh (2020c). River. [online] Banglapedia. Available at: https://en.banglapedia.org/index.php/River [Accessed 11 Jun. 2020].

Barman, R.P. and Islam, M. (2020). Root Causes and Consequences of Extreme Poverty in Northern Bangladesh. $A B C$ Research Alert, [online] 8(3), pp.139-146. Available at: https://abc.us.org/ojs/index.php/abcra/article/view/497 [Accessed 2 Apr. 2021].

BBS (2013). Statistical Yearbook of Bangladesh. Dhaka: Bangladesh Bureau of Statistics, Statistics Division, Ministry of Planning, Government of the People's Republic of Bangladesh.

Dhaka Tribune (2018). Water level continues to rise in Kurigram. [online] Dhaka Tribune. Available at: https://www.dhakatribune.com/bangladesh/environment/2018/06/25/water-level-continues-to-rise-in-kurigram [Accessed 12 Sep. 2021].

Dhaka Tribune (2020). Flood: More areas inundated in Kurigram, Nilphamari. Dhaka Tribune. [online] 28 Jun. Available at: https://www.dhakatribune.com/bangladesh/nation/2020/06/28/flood-more-areas-inundated-in-kurigram-nilphamari [Accessed 6 Sep. 2021].

Elahi, K.M. and Ara, I. (2008). Understanding the Monga in northern Bangladesh. Dhaka: Academic Press and Publishers Library.

Ferdous, J. and Mallick, D. (2019). Norms, practices, and gendered vulnerabilities in the lower Teesta basin, Bangladesh. Environmental Development, 31, pp.88-96.

Goodrich, C.G., Prakash, A. and Udas, P.B. (2019). Gendered vulnerability and adaptation in Hindu- Kush Himalayas: Research insights. Environmental Development, 31, pp.1-8.

Hossain, M.N., Uddin, M.N., Rokanuzzaman, M., Miah, M.A. and Alauddin, M. (2013). Effects of Flooding on SocioEconomic Status of Two Integrated Char Lands of Jamuna River, Bangladesh. Journal of Environmental Science and Natural Resources, [online] 6(2), pp.37-41. Available at: https://www.banglajol.info/index.php/JESNR/article/view/22093 [Accessed 10 Jun. 2020].

Islam, A. (2020). Flood inundates 17,135 hectares of croplands in Kurigram. [online] Dhaka Tribune. Available at: https://www.dhakatribune.com/bangladesh/nation/2020/09/27/flood-inundates-17-135-hectares-ofcroplands-in-kurigram [Accessed 3 Sep. 2021].

Kabir, Md.H. and Hossen, Md.N. (2019). Impacts of flood and its possible solution in Bangladesh. Disaster Advances, [online] 12, pp.48-57. Available at: https://www.researchgate.net/publication/336146425_Impacts_of_flood_and_its_possible_solution_in_Bangladesh [Accessed 12 May 2020].

Mirchandani, M. (2016). The Teesta water dispute: Geopolitics, myth and economics. [online] Observer Research Foundation. Available at: https://www.orfonline.org/research/teesta-water-dispute/ [Accessed 11 Jun. 2020]. 
Parveen, S. and Leonhäuser, I.-U. (2004). Empowerment of Rural Women in Bangladesh: A Household Level Analysis. In: Deutscher Tropentag - Berlin 2004. [online] Conference on Rural Poverty Reduction through Research for Development and Transformation. Available at: https://www.tropentag.de/2004/abstracts/full/382.pdf [Accessed 12 Jan. 2021].

Parvin, G.A., Shimi, A.C., Shaw, R.S. and Biswas, C. (2016). Flood in a Changing Climate: The Impact on Livelihood and How the Rural Poor Cope in Bangladesh. Climate, [online] 4(4), p.60. Available at: https://www.mdpi.com/2225-1154/4/4/60 [Accessed 22 Jul. 2020].

Paul, S.K. (2014). Determinants of evacuation response to cyclone warning in coastal areas of Bangladesh: a comparative study. Oriental Geographer, 55(1-2), pp.57-84.

Rahman, M.S. (2013). Climate Change, Disaster and Gender Vulnerability: A Study on Two Divisions of Bangladesh. American Journal of Human Ecology, [online] 2(2), pp.72-82. Available at: http://worldscholars.org/index.php/ajhe/article/view/0202_5/pdf [Accessed 12 Jun. 2020].

Rahman, S.U. (2014). IMPACTS OF FLOOD ON THE LIVES AND LIVELIHOODS OF PEOPLE IN BANGLADESH: A CASE STUDY OF A VILLAGE IN MANIKGANJ DISTRICT. [A Dissertation for the Degree of Master in Disaster Management] BRAC University. Available at: http://dspace.bracu.ac.bd/bitstream/handle/10361/3802/13168004.pdf?sequence=1 [Accessed 12 Sep. 2020].

Sharmin, S.N. (2014). Microcredit, Food Security and Women Empowerment in Bangladesh. [MS Thesis] Lund University. Available at: https://www.lunduniversity.lu.se/lup/publication/4461268 [Accessed 3 Dec. 2020].

Sultana, R., Hassan, M.Z. and Paul, S.K. (2018). Indigenous Practices for Coping with Flood: An Assessment of the Riparian People Living in the Teesta Floodplain. Rajshahi University Journal of Environmental Science, 7 , pp.18-29.

The Daily Star (2020). 3 lakh flood-hit people face drinking water crisis in Kurigram. The Daily Star. [online] 18 Jul. Available at: https://www.thedailystar.net/flood-in-bangaladesh-2020-3-lakh-people-face-drinking-water-crisis-1932229 [Accessed 16 Sep. 2020].

The World Bank (2017). Bangladesh Continues to Reduce Poverty But at Slower Pace. [online] The World Bank. Available at: https://www.worldbank.org/en/news/feature/2017/10/24/bangladesh-continues-to-reduce-poverty-but-at-slower-pace [Accessed 12 Jun. 2020].

Usman, R.A., Olorunfemi, F.B., Awotayo, G.P., Tunde, A.M. and Usm, B.A. (2013). Disaster Risk Management and Social Impact Assessment: Understanding Preparedness, Response and Recovery in Community Projects. In: S. Silvern and S. Young, eds., Environmental Change and Sustainability. [online] IntechOpen. Available at: https://www.intechopen.com/books/environmental-change-and-sustainability/disaster-risk-management-andsocial-impact-assessment-understanding-preparedness-response-and-recove [Accessed 22 May 2020].

Yufonyuy, N.D. (2015). Agricultural Contributions of Rural Women to Livelihood and Food Security: Case Study: Ngendzen Mbam, Nkum Sub Division, Cameroon. [Project Report] Available at: https://docplayer.net/58371080-Agricultural-contributions-of-rural-women-to-livelihood-and-food-securitycase-study-ngendzen-mbam-nkum-sub-division-cameroon.html [Accessed 26 Jun. 2020]. 